\title{
ATM germline mutations in women with familial breast cancer and a relative with haematological malignancy
}

\author{
Laura La Paglia $\cdot$ Anthony Laugé $\cdot$ Jérémie Weber $\cdot$ \\ Jérôme Champ · Eve Cavaciuti · Antonio Russo · \\ Jean-Louis Viovy · Dominique Stoppa-Lyonnet
}

Received: 30 September 2008/Accepted: 2 April 2009/Published online: 29 April 2009

(C) Springer Science+Business Media, LLC. 2009

\begin{abstract}
Biallelic inactivation of the $A T M$ gene causes ataxia-telangiectasia (A-T), a complex neurological disease associated with a high risk of leukaemias and lymphomas. Mothers of A-T children, obligate ATM heterozygote mutation carriers, have a breast cancer $(\mathrm{BC})$ relative risk of about 3 . The frequency of $A T M$ carriers in $\mathrm{BC}$ women with a BC family history has been estimated to be $2.70 \%$. To further our clinical understanding of familial BC and examine whether haematological malignancies are predictive of ATM germline mutation, we estimated the frequency of heterozygote mutation carriers in a series of $122 \mathrm{BC}$ women with a family history of both $\mathrm{BC}$ and haematological malignancy and without BRCAl/2 mutation. The gene screening was performed with a new high throughput method, EMMA (enhanced mismatch mutation analysis).
\end{abstract}

Electronic supplementary material The online version of this article (doi:10.1007/s10549-009-0396-z) contains supplementary material, which is available to authorized users.

L. L. Paglia · A. Laugé · J. Champ · D. Stoppa-Lyonnet ( $ه)$ Service de Génétique, Institut Curie-Hôpital, 75248 Paris, France

e-mail: dominique.stoppa-lyonnet@curie.net

L. L. Paglia · A. Russo

Department of Surgery and Oncology, Università di Palermo, 90127 Palermo, Italy

J. Weber - J. Champ

Fluigent, 75014 Paris, France

J. Champ $\cdot$ J.-L. Viovy

Centre de Recherche, Institut Curie, 75248 Paris, France

J. Champ $\cdot$ J.-L. Viovy

Unité CNRS UMR 168, 75248 Paris, France
Amongst 28 different ATM variants, eight mutations have been identified in eight patients: two mutations leading to a putative truncated protein and six being likely deleterious mutations. One of the truncating mutations was initially interpreted as a missense mutation, p.Asp2597Tyr, but is actually a splice mutation (c.7789G $>$ T/p.Asp2597_Lys 2643>LysfsX3). The estimated frequency of ATM heterozygote mutation carriers in our series is $6.56 \%$ (95\% CI: 2.16-10.95), a significantly higher figure than that observed in the general population, estimated to be between 0.3 and $0.6 \%$. Although a trend towards an increased frequency of $A T M$ carriers was observed, it was not different from that observed in a population of familial BC women not selected for haematological malignancy as the frequency of ATM carriers was $2.70 \%$, a value situated in the confidence interval of our study.

Keywords Ataxia-telangiectasia - Breast cancer . BRCA1 - BRCA2 - ATM - EMMA

\author{
E. Cavaciuti \\ Service de Biostatistiques, Institut Curie Hôpital, 75248 Paris, \\ France \\ E. Cavaciuti \\ Unité INSERM U900, 75248 Paris, France \\ E. Cavaciuti \\ Ecole des Mines de Paris, ParisTech, 77300 Fontainebleau, \\ France \\ D. Stoppa-Lyonnet \\ Unité INSERM U830, 75248 Paris, France \\ D. Stoppa-Lyonnet \\ Université Paris Descartes, 75270 Paris, France
}




\section{Introduction}

Breast cancer (BC) is the most common cancer in western countries. Most cases of $\mathrm{BC}$ are sporadic, but almost $13 \%$ of women have at least one first-degree relative with $\mathrm{BC}$ [1]. The BRCA1 and BRCA2 genes are the two genes whose germline monoallelic inactivating mutations are identified in $15-20 \%$ of women with $\mathrm{BC}$ and a strong family history of $\mathrm{BC}$ [2], suggesting the presence of other $\mathrm{BC}$ predisposing genes explaining at least a portion of the remaining non-mutated familial cases. Three other genes are associated with an increased BC risk: TP53, STK11, and PTEN. As mutations of these genes are associated with rare autosomal dominant syndromes, these genes must be considered in a specific familial context. They also have a very small contribution to familial aggregations ( $<1 \%$ of familial cases) [2]. The ATM gene (ataxia telangiectasia mutated) encodes a lipid kinase phosphatidylinositol 3-kinase (PI3K) expressed in a wide range of tissues. It is the apex of a signalling cascade that detects and repairs DNA double-strand breaks, a cascade in which the BRCA1 and BRCA2 proteins are involved [3, 4]. Biallelic inactivation of the ATM gene causes ataxia-telangiectasia (A-T), a neurodegenerative disorder that develops in early childhood. Ataxia-telangiectasia children present a severe clinical phenotype characterised by progressive cerebellar ataxia and dysarthria, associated with ocular telangiectasia, immunodeficiency, sensitivity to ionising radiation, and an increased risk of cancers, especially leukaemias and lymphomas [5]. A large number of ATM mutations have been identified, extending over a very long $10 \mathrm{~kb}$ coding sequence scattered in 62 exons. Point or small size mutations and large gene rearrangements have been identified and some deleterious missense mutations located in the PI3K domain have been reported (ATM mutation database: http://chromium.liacs.nl/LOVD2/ home.php) [6, 7].

The mothers of A-T children, obligate ATM heterozygote mutation carriers, have been shown to present an increased BC risk [8]. Additional studies conducted in families of A-T children have shown a relative risk (RR) of about three attributable to ATM heterozygosity in women [9-12]. Various BC population studies have tried to estimate the risk of developing BC amongst ATM mutation carriers, sometimes with controversial results, as reviewed in Ahmed and Rahman [13]. In a more recent study, Renwick et al. analysed 443 cases of familial BC and 521 controls, and found 12 women carrying an ATM mutation in the case group $(2.70 \%)$ and two in the control group $(0.38 \%)$ [14]. They estimated that ATM mutation heterozygosity was associated with a BC RR of 2.37 (95\% CI: 1.51-3.78) [14]. As the rate of BRCA1/2 mutation detection in $\mathrm{BC}$ women with a family history of $\mathrm{BC}$ is $15-20 \%$, the rate of $A T M$ mutations is five to seven times lower than the rate of $B R C A 1 / 2$ mutations.

ATM mutations are involved in the development of lymphoid malignancies as A-T patients are at high risk of T-cell acute lymphocytic leukaemia (T-ALL) and especially prolymphocytic leukaemia (T-PLL) [15]. Somatic inactivation of the ATM gene has been reported in T-PLL and B-cell chronic lymphocytic leukaemia (B-CLL) occurring in patients outside an A-T context [16-18]. Mutations observed in these reports are essentially missense mutations and mostly occur in the PI3 $\mathrm{K}$ domain. Monoallelic ATM germline mutations have also been reported in some patients with B-CLL, mantle cell lymphoma (MCL), and T-cell ALL [19-22]. In Stankovic's series, $18 \%$ of patients were carriers of a monoallelic ATM germline mutation [19]. In a short series of T-ALL affected children, a monoallelic ATM germline mutation was identified in $20 \%$ of cases [23]. In a Nordic study of relatives of A-T children, an increased standardised incidence ratio (SIR) of 37 (95\% CI: 13-80) was observed for leukaemias and non-Hodgkin lymphomas [11]. A trend towards an increased RR of leukaemias and lymphomas was also observed in a French study of the relatives of A-T children [24].

To further our clinical understanding of familial $\mathrm{BC}$ without $B R C A 1 / 2$ mutation and to limit the volume of $A T M$ gene screening, we estimated the frequency of $A T M$ mutation carriers in $\mathrm{BC}$ women with a family history of both $\mathrm{BC}$ and haematological malignancy. In other words, this study was designed to examine whether the presence of leukaemia and/or lymphoma amongst relatives in BC families was a predictive factor for ATM mutation. A second objective was to report a new high throughput method, called enhanced mismatch mutation analysis (EMMA), that we have adapted for ATM gene mutation screening. We report the results of EMMA $A T M$ gene analysis in a series of 122 unrelated BRCA1 and BRCA2 mutation negative women with at least one-first or second degree relative with leukaemia or lymphoma.

\section{Patients and methods}

\section{Patients}

Between January 1995 and December 2005, 2,009 unrelated patients with $\mathrm{BC}$ (index case) were tested for $B R C A I$ and $B R C A 2$ mutations at the Institut Curie. They had a family history of breast and/or ovarian cancer and/or developed $\mathrm{BC}$ before the age of 36 . A family history was defined as either two first-degree relatives with cancer: (1) at least one with invasive BC before the age of 41, or (2) one with ovarian cancer or breast cancer at any age, or 
three first-degree or second degree relatives from the same lineage with invasive $\mathrm{BC}$ or ovarian cancer at any age, where the index case constituted one of the cases. Amongst the 1,629 patients with negative BRCAl and BRCA2 screening, 122 had at least one-first or second degree relative with leukaemia or lymphoma, and this relative belonged to the branch of the family in which breast cancers were segregating. Informed consent for breast cancer genetic studies was obtained from each woman at the family cancer clinic.

\section{DNA preparation}

Two DNA extraction methods from whole blood were used: (1) a modified perchlorate/chloroform procedure [25], or (2) a rapid method using the NucleoSpin Blood extraction kit (Macherey-Nagel; ref. http://www.mn-net.com). DNA concentrations and the quality of each sample were determined spectrophotometrically at 260/280 nm (NanoDrop ${ }^{\circledR}$ ND-1000, NanoDrop technologies).

\section{EMMA}

The enhanced mismatch mutation analysis, EMMA (Fluigent, France), is a method of mutation screening based on heteroduplex analysis (HDA). Heteroduplexes and homoduplexes are separated by their different electrophoretic mobility due to their conformational differences. The resolution of EMMA is considerably better than that of standard HDA due to a combination of high resolution blockcopolymer sieving matrix, and nucleosides as additives in the electrophoretic medium [26, 27]. The medium was loaded on the ABI3130XL sequencing system (Applied Biosystems 2006). EMMA also allows simultaneous analysis of numerous amplicons by multiplex analysis. This method allows the simultaneous detection of both small mutations and large gene rearrangements (LGR) by applying semiquantitative PCR conditions and an external control amplicon [28]. As a result of multiplex analysis and LGR detection, EMMA is a high throughput screening mutation method. Data analysis was performed with Emmalys ${ }^{(}$ software (Fluigent, France) for both point and small mutations and Excel Visual Basic macro for LGR analysis.

Amplicon and multiplex design

Primers were designed using the web-based Primer3 software (http://frodo.wi.mit.edu/cgi-bin/primer3/primer3_www. cgi) to cover the 62 coding exons of the ATM gene and the splice site junctions. A series of 36 multiplexes of 2-4 amplicons, including the external gene control, was prepared. Amplicon sizes ranged between 217 and $567 \mathrm{bp}$ (basepair). In a given multiplex, the length difference between two adjacent amplicons was at least $50 \mathrm{bp}$. Primer sequences and multiplex amplicon PCR conditions are reported in Table S1 (supplementary data).

\section{EMMA PCR conditions}

PCR conditions were identical for all multiplexes. About $100 \mathrm{ng}$ of DNA were amplified using Taq ABgene $0.06 \mathrm{U} /$ $\mu \mathrm{l}$ (ABgene UK, ref: www.abgene.com), $5 \mathrm{mM} \mathrm{MgCl}_{2}$, $4 \times 0.2 \mathrm{mM}$ dNTPs, and $0.08-0.3 \mu \mathrm{M}$ of each primer in a final reaction volume of $20 \mu$ l. Cycling conditions were as follows: $94^{\circ} \mathrm{C}$ for $5 \mathrm{~min}$, followed by 25 cycles of $94^{\circ} \mathrm{C}$ for $30 \mathrm{~s}, 58^{\circ} \mathrm{C}$ for $30 \mathrm{~s}$, and $72^{\circ} \mathrm{C}$ for $30 \mathrm{~s}$, followed by two steps of $72^{\circ} \mathrm{C}$ for $7 \mathrm{~min}$ and $98^{\circ} \mathrm{C}$ for $10 \mathrm{~min}$. Heteroduplex formation consisted of 73 cycles of $98^{\circ} \mathrm{C}$ for $30 \mathrm{~s}$, with temperature decreasing by $1^{\circ}$ at each cycle, and a final step at $25^{\circ} \mathrm{C}$ for $10 \mathrm{~min}$.

\section{DNAs for EMMA validation study}

As small insertions or deletions have been shown to be easily detected by EMMA, we focused our validation study on nucleotide substitutions previously detected by direct sequence analysis [27]. DNAs from A-T children or their $A T M$ heterozygote carrier relatives, previously referred to our laboratory, were selected for nucleotide substitutions. DNAs carrying a substitution were available for 49 amplicons. The substitutions studied are reported in Table S2 (supplementary data).

A heterozygote ATM deletion from exons 26-65 was also used to validate LGR detection. An amplicon containing exon 8 or 11 of the $R B 1$ gene was used as external control [29]. DNAs from these A-T patients were used as experimental controls in the study of the $122 \mathrm{BC}$ patients.

\section{Sequencing of EMMA variant profiles}

Each DNA corresponding to a different EMMA profile as compared with the majority of profiles was sequenced.

$100 \mathrm{ng}$ of DNAs were amplified using Taq ABgene $0.025 \mathrm{U} / \mu \mathrm{l}$ (ABgene UK, ref: www.abgene.com), $4 \times$ $0.2 \mathrm{mM}$ dNTPs, $1.5 \mathrm{mM} \mathrm{MgCl} 2$, and $0.3 \mu \mathrm{M}$ of each primer in a final reaction volume of $50 \mu$ l. Amplification was performed with a touchdown PCR protocol consisting of an initial denaturation step at $94^{\circ} \mathrm{C}$ for 5 min followed by 35 PCR cycles: denaturation at $94^{\circ} \mathrm{C}$ for $30 \mathrm{~s}$, annealing for $30 \mathrm{~s}$ with temperature gradually decreasing from $60^{\circ} \mathrm{C}$ to $52^{\circ} \mathrm{C}$ for 35 cycles, and elongation at $72^{\circ} \mathrm{C}$ for $30 \mathrm{~s}$.

PCR products were separated by agarose gel electrophoresis, purified (Macherey Nagel), and sequenced, using one of the PCR primers (usually the forward primer, except in the case of poor sequence quality), Big Dye Cycle Sequencing Reactions and an ABI3130XL automated 


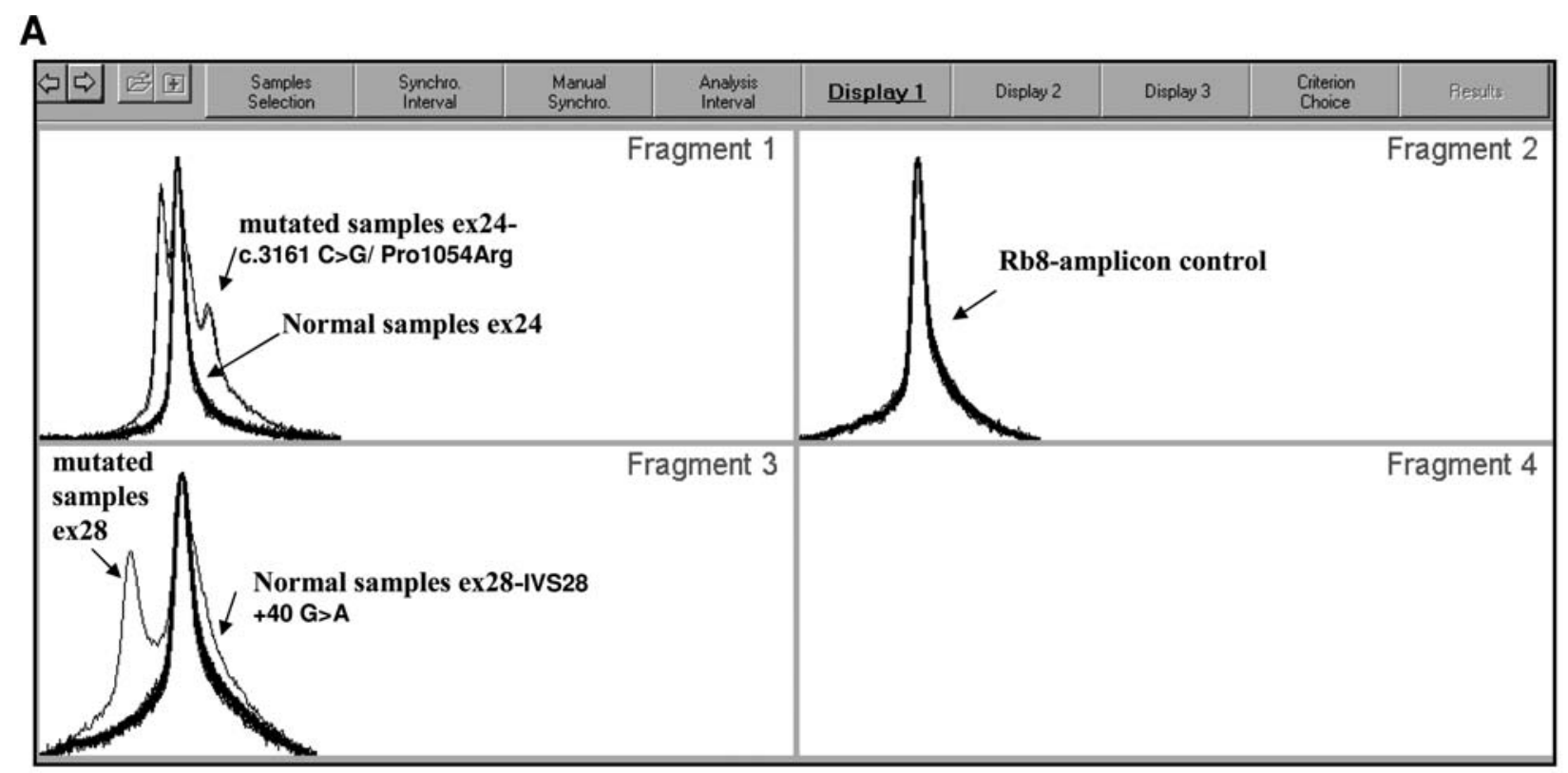

\section{B}

ATM Ex 24


Fig. 1 Emma analysis of the multiplex amplified ATM exons 24, 28, and $R B 1$ exon 8 . a The profiles of 93 EMMA analysed DNAs were superimposed with Emmalys ${ }^{\circledR}$ software. Each peak corresponds to a single amplified exon or amplicon. Fragment 1 is ATM exon 24. Two profiles were identified: (1) a single peak profile detected in 90 DNAs, and (2) a triple peak profile detected in three DNAs with a heterozygous c.3161C $>$ G/p.Pro1054Arg polymorphism. Fragment 2 is $R B 1$ exon 8 , used as external control for LGR detection. Only one peak profile was detected. Fragment 3 is ATM exon 28. Two profiles were identified: (1) a single peak profile detected in 92 DNAs, and (2)

a double peak profile detected in 1 DNA with the heterozygous IVS28, c.3993+40G $>$ A variant. b Individual DNA profiles of ATM 24 and 28 amplicons obtained with Emmalys ${ }^{\odot}$ software. Regarding exon 24, 5 DNAs lead to a normal profile $(2 a-6 a)$. The 1a profile has three peaks and corresponds to the superimposition of the c.3161C/ p.Pro1054 and the c.3161G/p.Arg1054 alleles. Regarding exon 28, 5 DNAs lead to a normal profile $(1 b, 3 b-6 b)$. The $2 b$ profile has two peaks and corresponds to the superimposition of the IVS28, c. $3993+40 \mathrm{G}$ and IVS28, c. $3993+40$ A alleles 
sequencer (Applied Biosystems). Seqscape ${ }^{\circledR}$ (Applied Biosystems) software was used for sequence analysis.

The ATM coding sequence reference is U33841. The first translated nucleotide is the reference nucleotide.

Control DNAs for analysing the population frequency of sequence variants identified in the $122 \mathrm{BC}$ cases

The frequency of DNA variants detected in the series of 122 BC women was determined in a series of 93-186 unrelated controls. Controls were children tested for $R B 1$ gene mutation due to the presence of retinoblastoma, a disease unrelated to the ATM gene and for which our laboratory routinely performs mutation screening.

The arbitrary threshold of $1 \%$ was selected according to the definition of polymorphism in population genetics: a DNA variant with a frequency of $1 \%$ or above was rather considered with no functional effect.
Splice site score predictions

The genomic sequence environment of a DNA variant was analysed using Splice Site Prediction by Neural Network (NNSPLICE available at http://www.fruitfly.org/seq_tools/ splice.html), Splice Site Finder (SSF available at http:// violin.genet.sickkids.on.ca/ ali/splicesitefinder.html), Max EntScan (MES available at http://genes.mit.edu/burgelab/ maxent/Xmaxentscan_scoreseq.html) [30].

Protein conservation and A-GVGD score

The A-GVGD algorithm developed by Tavtigian et al. for the analysis of various genes, including the ATM gene, was used to contribute to discriminate disease-causing missense mutations from neutral changes (http://agvgd.iarc.fr/) [31, 32]. This algorithm combines the biophysical characteristics of amino acid changes $(\mathrm{GV})$ and alignments of protein

Table 1 ATM germline variants and their characteristics in 122 BC patients with a family history of breast and haemotological malignancy

\begin{tabular}{|c|c|c|c|c|c|c|c|c|c|}
\hline $\begin{array}{l}\text { Nucleotide } \\
\text { change }\end{array}$ & $\begin{array}{l}\text { Amino acid } \\
\text { change }\end{array}$ & $\begin{array}{l}\text { Exon/ } \\
\text { IVS }\end{array}$ & $\begin{array}{l}\text { Freq. in } \\
\text { patients }\end{array}$ & $\begin{array}{l}\text { Freq. in } \\
\text { controls }\end{array}$ & $\begin{array}{l}\text { FAT or PI3K } \\
\text { domain }\end{array}$ & $\begin{array}{l}\text { GV } \\
\text { score }\end{array}$ & $\begin{array}{l}\text { GD } \\
\text { score }\end{array}$ & $\begin{array}{l}\text { A-GVGD combined } \\
\text { score and prediction }\end{array}$ & $\begin{array}{l}\text { Signification } \\
\text { proposed }\end{array}$ \\
\hline c. $4852 \mathrm{C}>\mathrm{T}$ & p.Arg1618X & exon 34 & $1 / 122$ & $0 / 186$ & - & - & - & - & Deleterious \\
\hline c. $7789 \mathrm{G}>\mathrm{T}$ & $\begin{array}{l}\text { p.Asp2597_Lys2643 } \\
\text { >LysfsX3 }\end{array}$ & exon 55 & $1 / 122$ & $0 / 186$ & - & - & - & - & Deleterious \\
\hline c. $749 \mathrm{G}>\mathrm{A}$ & p.Arg250Gln & exon 9 & $1 / 122$ & $0 / 186$ & - & 0.00 & 42.81 & $\mathrm{C} 35$ & Likely deleterious \\
\hline c. $6067 \mathrm{G}>\mathrm{A}$ & p.Gly2023Arg & exon 43 & $1 / 122$ & $1 / 186$ & FAT & 0.00 & 125.13 & C65 & Likely deleterious \\
\hline c. $7187 \mathrm{C}>\mathrm{G}$ & p.Thr2396Ser & exon 51 & $1 / 122$ & $0 / 93$ & FAT & 111.69 & 6.18 & $\mathrm{C} 0$ & Likely deleterious \\
\hline c. $7305 \mathrm{C}>\mathrm{G}$ & p.Asn2435Lys & exon 51 & $1 / 122$ & $0 / 93$ & FAT & 0.00 & 93.88 & C65 & Likely deleterious \\
\hline c. $8560 \mathrm{C}>\mathrm{T}$ & p.Arg2854Cys & exon 60 & $1 / 122$ & $0 / 93$ & PI3K & 42.81 & 154.23 & $\mathrm{C} 35$ & Likely deleterious \\
\hline c. $9023 \mathrm{G}>\mathrm{A}$ & p.Arg3008His & exon 65 & $1 / 122$ & $0 / 186$ & PI3K & 0.00 & 28.82 & $\mathrm{C} 25$ & Likely deleterious \\
\hline c. $1952 \mathrm{~T}>\mathrm{C}$ & p.Leu651Pro & exon 15 & $1 / 122$ & $4 / 186$ & - & 0.00 & 97.78 & C65 & Unknown \\
\hline c. $2119 \mathrm{~T}>\mathrm{C}$ & p.Ser707Pro & exon 15 & $3 / 122$ & $0 / 186$ & - & 73.35 & 0.00 & $\mathrm{C} 0$ & Unknown \\
\hline c. $2254 \mathrm{C}>\mathrm{G}$ & p.Leu752Val & exon 17 & $1 / 122$ & $0 / 186$ & - & 0.00 & 30.92 & $\mathrm{C} 25$ & Unknown \\
\hline c. $2289 \mathrm{~T}>\mathrm{A}$ & p.Phe763Leu & exon 17 & $2 / 122$ & $0 / 186$ & - & 157.56 & 0.00 & $\mathrm{C} 0$ & Unknown \\
\hline c. $2476 \mathrm{~A}>\mathrm{C}$ & p.Ile826Leu & exon 19 & $1 / 122$ & $0 / 186$ & - & 141.80 & 4.86 & $\mathrm{C} 0$ & Unknown \\
\hline c. $4556 \mathrm{~T}>\mathrm{C}$ & p.Val1519Ala & exon 32 & $1 / 122$ & $8 / 186$ & - & 0.00 & 65.28 & C65 & Unknown \\
\hline c. $4802 \mathrm{G}>\mathrm{A}$ & p.Ser1601Asn & exon 34 & $1 / 122$ & $0 / 186$ & - & 115.58 & 0.00 & $\mathrm{C} 0$ & Unknown \\
\hline c. $4975 \mathrm{~A}>\mathrm{G}$ & p.Ile1659Val & exon 35 & $1 / 122$ & $0 / 93$ & - & 93.66 & 0.00 & $\mathrm{CO}$ & Unknown \\
\hline c. $5018 \mathrm{G}>\mathrm{C}$ & p.Ser1673Thr & exon 36 & $1 / 122$ & $0 / 186$ & - & 111.49 & 0.00 & $\mathrm{C} 0$ & Unknown \\
\hline c. $6844 \mathrm{~A}>\mathrm{C}$ & p.Asn2282His & exon 49 & $1 / 122$ & $1 / 186$ & FAT & 64.77 & 36.57 & $\mathrm{CO}$ & Unknown \\
\hline c. $6919 \mathrm{C}>\mathrm{T}$ & p.Leu2307Phe & exon 49 & $1 / 122$ & $1 / 186$ & FAT & 0.00 & 21.82 & $\mathrm{C} 15$ & Unknown \\
\hline c. $1899-24 \mathrm{~A}>\mathrm{G}$ & - & IVS14 & $1 / 122$ & $0 / 186$ & - & - & - & - & Unknown \\
\hline c. $3993+40 \mathrm{G}>\mathrm{A}$ & - & IVS28 & $1 / 122$ & $0 / 186$ & - & - & - & - & Unknown \\
\hline c. $4237-54 \mathrm{~T}>\mathrm{C}$ & - & IVS30 & $4 / 122$ & $1 / 186$ & - & - & - & - & Unknown \\
\hline c. $4437-7 \mathrm{~A}>\mathrm{C}$ & - & IVS31 & $1 / 122$ & $0 / 186$ & - & - & - & - & Unknown \\
\hline c. $6807+39 \mathrm{C}>\mathrm{T}$ & - & IVS48 & $2 / 122$ & $0 / 185$ & - & - & - & - & Unknown \\
\hline c. $7516-32 \mathrm{~T}>\mathrm{G}$ & - & IVS52 & $1 / 122$ & $0 / 93$ & - & - & - & - & Unknown \\
\hline c. $7927+69 \mathrm{~T}>\mathrm{C}$ & - & IVS55 & $1 / 122$ & $0 / 186$ & - & - & - & - & Unknown \\
\hline c. $3342 \mathrm{G}>\mathrm{A}$ & p.Lys1114Lys & exon 25 & $1 / 122$ & $1 / 149$ & - & - & - & - & Unknown \\
\hline c. $685 \mathrm{C}>\mathrm{T}$ & p.Leu229Leu & exon 9 & $1 / 122$ & $5 / 186$ & - & - & - & - & Likely neutral \\
\hline
\end{tabular}


sequences of different and phylogenetically distant species (GD), from human to zebrafish. The output from AlignGVGD is an ordered series of grades ranging from C65 (most likely deleterious) to $\mathrm{C} 0$ (most likely neutral). Missense mutations with a score below $\mathrm{C} 15$ are considered as probably neutral. When the score is at or above $\mathrm{C} 15$ and below $\mathrm{C} 35$, missense mutations remain unclassified, at or above C35 they are likely deleterious [32].

\section{Results}

EMMA validation for the ATM gene study

All of the 49 nucleotide substitutions located in 49 different amplicons of the ATM gene and selected regardless of their biological significance were detected (Fig. 1 and data not shown, see supplementary data for the list of mutations studied, Table S2). The deletion of exons 26-65 was detected in all corresponding amplicons.

EMMA analysis in the series of 122 women

with familial $\mathrm{BC}$ and one relative

with haematological malignancy

A total of 28 different monoallelic sequence variants were identified in 35 of the $122 \mathrm{BC}$ women screened for ATM gene mutation. These variants were initially interpreted as follows: 1 nonsense mutation, 18 missense mutations, 2 silent mutations, 7 intronic variants (Table 1). No LGR was detected.

Twenty-two heterozygous polymorphisms were also detected and were classified as polymorphisms on the basis of previous reports in the literature, in databases, especially the NCBI SNP database, or in A-T patients studied in our laboratory (data not shown) (Table 2).

A nonsense mutation: c. $4852 \mathrm{C}>\mathrm{T} / \mathrm{p} \cdot \operatorname{Arg} 1618 \mathrm{X}$ was identified in one patient. This mutation, leading to a putative truncated and non-functional protein was considered to be deleterious.

The biological function of the 18 missense mutations identified was unknown, as they have not been previously reported as deleterious in databases. The following five criteria were used to assess the significance of their functional effect: (1) a carrier frequency $<1 \%$ in a series of controls, (2) identification of the missense mutation in an A-T child carrying no more than one deleterious ATM mutation, (3) location in an ATM protein domain known to be functionally important, especially the PIK3 and FAT domains, (4) the importance of the amino acid (aa) change and aa species conservation analysed by the A-GVGD algorithm, and (5) a putative splice effect by using in silico splice site score prediction models. These criteria are listed in order of increasing relevance with respect to a putative deleterious effect.

In one case, a splicing defect was suspected on in silico analyses, as the c.7789G $>\mathrm{T}$ mutation, initially interpreted as p.Asp2597Tyr, is actually a splicing mutation. c. $7789 \mathrm{G}$ is the first nucleotide of exon 55. The $\mathrm{G}>\mathrm{T}$ substitution leads to disruption of the acceptor site of intron 54 and a putative truncated protein of 2,598 aa (c.7789_7927del139/ p.Asp2597_Lys2643>LysfsX3). This splicing defect was confirmed by RNA analysis of patient lymphoblasts showing loss of exon 55 (Fig. 2). This mutation was identified in only one patient.

The remaining 17 missense mutations were classified into three categories according to the above criteria: likely deleterious, unknown variants (UV), and likely neutral.

Six missense mutations were classified as likely deleterious: p.Arg250Gln, p.Gly2023Arg, p.Thr2396Ser, p.Asn 2435Lys, p.Arg2854Cys, and p.Arg3008His (Table 1). They were considered as "likely deleterious" according to the AGVGD algorithm except for p.Thr2396Ser and p.Arg 3008 His which were respectively "neutral" or "unclassified". These missense mutations were located in the FAT

Table 2 Identified ATM variants classifoed as polymorphisms in 122 BC patients with a family history of breast and haematological malignancy

\begin{tabular}{|c|c|c|c|}
\hline Nucleotide change & Amino acid change & Exon/IVS & Het. freq. (\%) \\
\hline c. $544 \mathrm{G}>\mathrm{C}$ & p.Val182Leu & exon 8 & 2.0 \\
\hline c. $2442 \mathrm{C}>\mathrm{A}$ & p.Asp 814Glu & exon 18 & 1.3 \\
\hline c. $2572 \mathrm{~T}>\mathrm{C}$ & p.Phe858Leu & exon 19 & 1.5 \\
\hline c. $3161 \mathrm{C}>\mathrm{G}$ & p.Pro1054Arg & exon 24 & 1.9 \\
\hline c. $4258 \mathrm{C}>\mathrm{T}$ & p.Leu1420Phe & exon 31 & 3.1 \\
\hline c. $4578 \mathrm{C}>\mathrm{T}$ & p.Pro1526Pro & exon 32 & 4.4 \\
\hline c. $5557 \mathrm{G}>\mathrm{A}$ & p.Asp1853Asn & exon 39 & 10.6 \\
\hline c. $5558 \mathrm{~A}>\mathrm{T}$ & p.Asp1853Val & exon 39 & 1.1 \\
\hline c. $1899-55 \mathrm{~T}>\mathrm{G}$ & - & IVS14 & 2.4 \\
\hline c. $2125-68 \mathrm{~T}>\mathrm{C}$ & - & IVS15 & 3.7 \\
\hline c. $2250+22 \mathrm{~A}>\mathrm{C}$ & - & IVS16 & 1.2 \\
\hline c. $2250+34 \mathrm{~A}>\mathrm{C}$ & - & IVS16 & 1.2 \\
\hline c. $2250+78 \mathrm{G}>\mathrm{A}$ & - & IVS16 & 1.9 \\
\hline c. $2839-90 \mathrm{~T}>\mathrm{G}$ & - & IVS20 & 38.0 \\
\hline c.3403-14insA & - & IVS25 & 49.0 \\
\hline c.3285-9del & - & IVS24 & 11.0 \\
\hline c. $3747-34 \mathrm{~A}>\mathrm{G}$ & - & IVS27 & 1.0 \\
\hline c. $3993+48 \mathrm{~A}>\mathrm{G}$ & - & IVS28 & 1.3 \\
\hline c. $4777-20 \mathrm{~A}>\mathrm{G}$ & - & IVS33 & 1.0 \\
\hline c. $5497-8 \mathrm{~T}>\mathrm{C}$ & - & IVS38 & 1.5 \\
\hline c. $5497-15 \mathrm{G}>\mathrm{C}$ & - & IVS38 & 1.0 \\
\hline c. $8786+8 \mathrm{~A}>\mathrm{C}$ & - & IVS62 & 1.1 \\
\hline
\end{tabular}

Het. freq. Heterozygote frequency according to NCBI 
protein domain and were not detected in a set of control DNAs. They have also been previously reported in a T-PLL, a feature that may argue in favour of their deleterious effect as they could have been selected by the tumour process [16]. In addition, the p.Arg3008His missense mutation has been detected in an A-T child whose second mutation was introducing an ATM stop codon (Micol et al., in preparation). These six missense mutations were identified in six patients.

Eleven missense mutations were classified as UV: p.Leu651Pro, p.Ser707Pro, p.Leu752Val, p.Phe763Leu, p.Ile826Leu, p.Val1519Ala, p.Ser1601Asn, p.Ile1659Val, p.Ser1673Thr, p.Asn2282His, and p.Leu2307Phe (Table 1). The majority of these UV were not located in the PI3K or FAT domains, and the A-GVGD scores were in favour of unclassified or neutral effect except in two cases. Regarding the p.Leu651Pro and p.Val1519Ala missense mutations, although their A-GVGD score was in favour of a likely deleterious effect, they were classified as UV as their carrier frequency amongst controls was high, respectively above 2 and $4 \%$ (Table 1). These 11 missense mutations were identified in 14 patients.

Two silent and seven intronic variants were also detected. Only criteria (1), (2), and (5) quoted above can be used. The in silico analyses did not suggest a splicing defect in any of these nine variants. The frequency of the seven intronic variants was $<1 \%$ in our series of controls; they were therefore classified as UV: IVS14, c1899-24A $>$ G; IVS28, c.3993+40G $>$ A; IVS30, c.4237-54T $>$ C; IVS31, c.4437$7 \mathrm{~A}>\mathrm{C}$; IVS48, c.6807+39C $>\mathrm{T}$; IVS52, c.7516-32T $>\mathrm{G}$; IVS55, c.7927+69T $>$ C. The p.Lys1114Lys variant was also classified as UV, as its frequency in the control group was $<1 \%$. The p.Leu229Leu silent variant was classified as likely neutral, since its frequency in controls was $>1 \%$.

In summary, a total of eight patients carrying an ATM mutation, two patients with a truncating mutation and six patients with a likely deleterious ATM mutation, were identified in this series of 122 patients. The frequency of ATM heterozygote mutation carriers is $6.56 \%(95 \% \mathrm{CI}$ : 2.16-10.95).

\section{A}



B

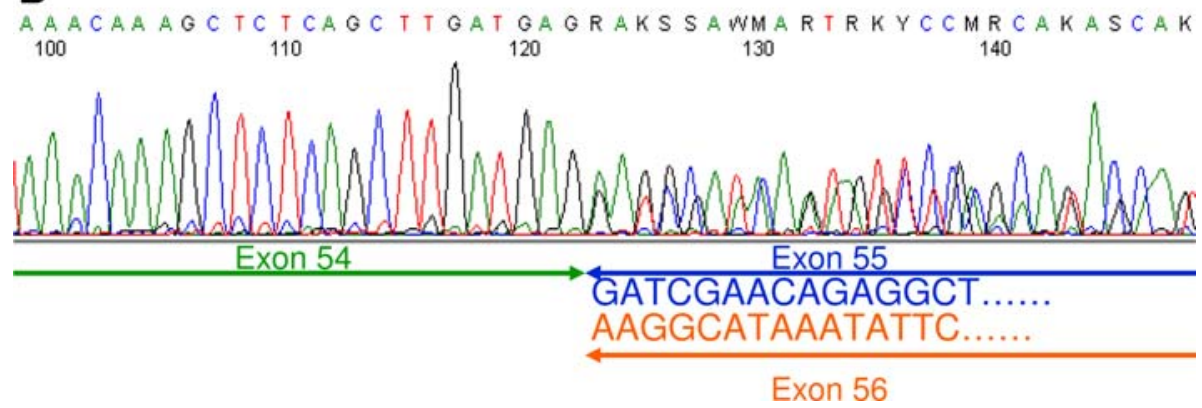

Fig. 2 cDNA analysis of the c.7789G $>$ T mutation. a Initially interpreted as a missense mutation, the c. $7789 \mathrm{G}>\mathrm{T}$ substitution is a splicing mutation as shown by cDNA analysis of a lymphoblast cell line established from the patient carrying this mutation. Exons 54-59 were amplified from primers located in the coding sequence (sequence available on request). The amplified product was analysed by $1.5 \%$ agarose gel electrophoresis. One 756 bp long fragment was obtained from a control lymphoblast cell line; an additional fragment, $617 \mathrm{bp}$ long, was detected in the c.7789G $>\mathrm{T}$ mutant cell line, suggesting that exon 55 deletion has occurred. b Sequence of the 5459 amplified exons from the c.7789G $>$ T mutant cell line. Superimposition of the 54-55 and 54-56 exon junctions confirms the exon 55 deletion. The c.7789G $>\mathrm{T}$ substitution leads to the putative truncated p.Asp2597_Lys2643>LysfsX3 protein 


\section{Discussion}

Epidemiological studies designed to elucidate the role of ATM mutations in cancer risks are limited by the large size of the gene and the large number of mutations spread throughout the coding sequence. To simplify the extensive laboratory work required for ATM screening, a new DNA analysis method was applied. Using similar analysis conditions for each amplicon, all of the 49 different control mutations previously identified by direct sequencing in
A

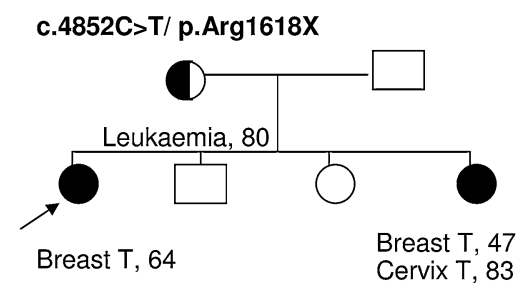

c.7789_7927del139/p.Asp2597_Lys2643>LysfsX3

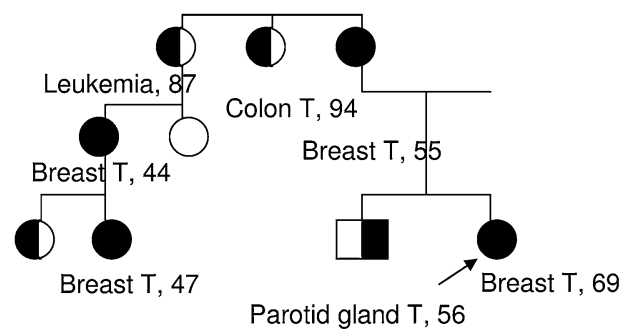

c.749G>A/p.Arg250GIn
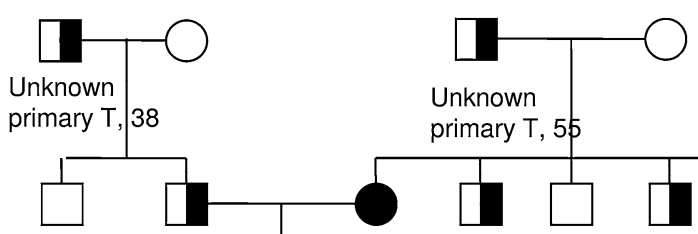

Cutaneous T, 51 Breast T, 49 Larynx T, 65



Breast T, 39

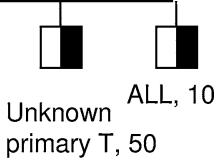

c.6067G>A/p.Gly2023Arg

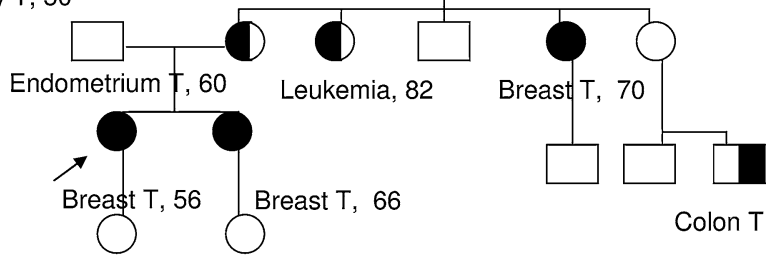

B
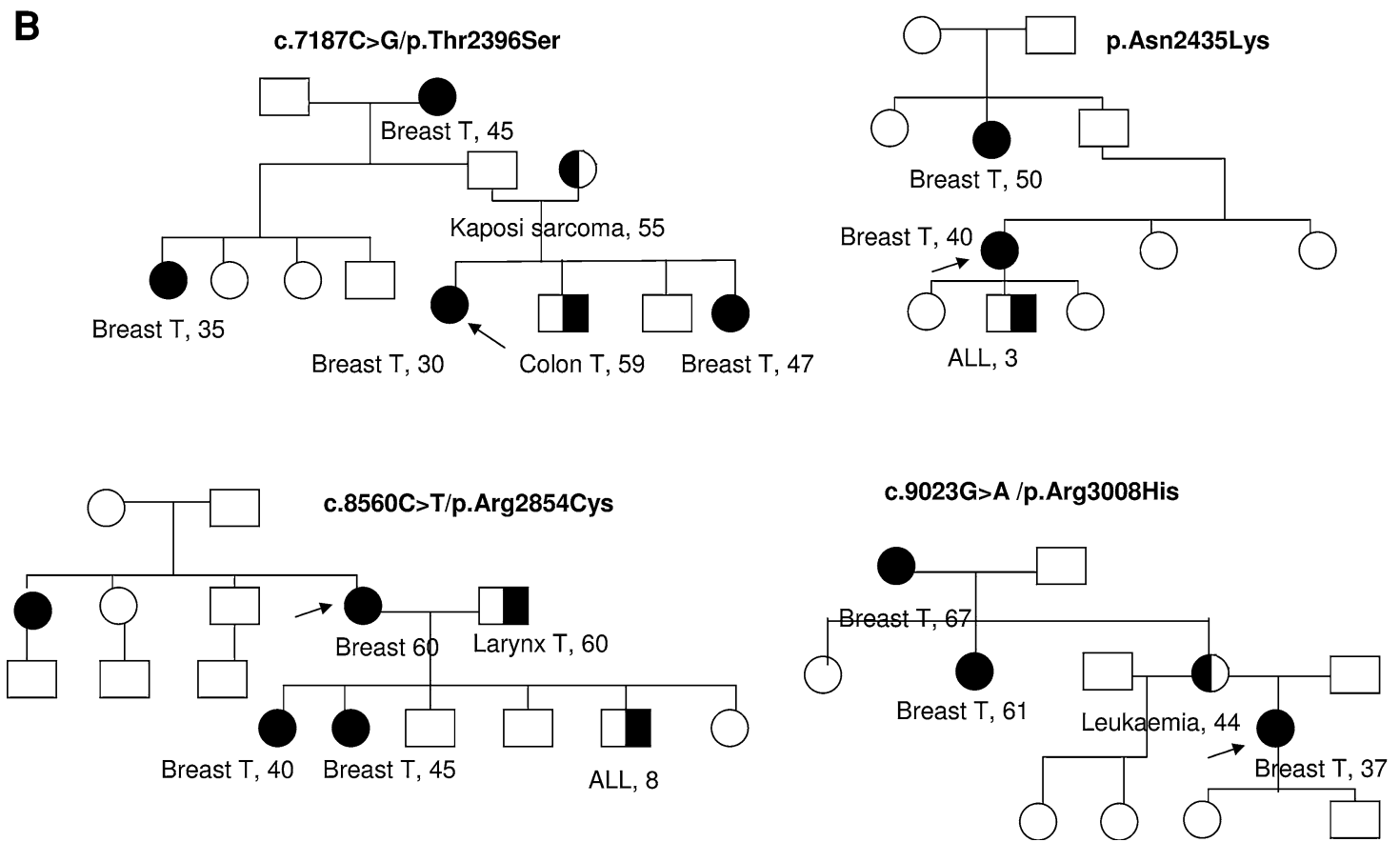

Fig. 3 Family history of the eight patients carrying a deleterious or likely deleterious ATM mutation. The BC women tested for ATM mutation are indicated by an arrow. ALL: acute lymphoid leukaemia 
A-T children and a large gene deletion were detected by EMMA. Multiplex analysis including the search for LGR allowed screening of the $10 \mathrm{~kb}$ ATM coding sequence in 3 weeks in a large set of 94 patients.

In the series of $122 \mathrm{BC}$ women with a relative with haematological malignancy, two deleterious mutations, leading to a putative truncated protein were identified, a nonsense mutation, and a splicing mutation not previously reported and characterised. The remaining 17 missense mutations were classified into three categories: six likely deleterious mutations, nine mutations of unknown significance, and two likely neutral mutations. The main criterion used to classify these missense mutations was the AGVGD score. Moreover, p.Gly2023Arg, p.Thr2396Ser, and p.Arg3008His variants have been reported as somatic events in T-PLL or B-CLL and associated with loss of the second ATM allele by $11 \mathrm{q}$ deletion, features that argue strongly in favour of their deleterious effect as they could have been selected by the tumour process [16, 33]. The multiplicity of criteria to assess the significance of the functional effect of a DNA variant underlines that none a criterion alone is sufficient and that they have to be altogether taken into account with in some cases when they are leading to divergent conclusions the need to make some arbitrary decisions. The availability of functional testing and in vitro functional assays allowing characterisation of missense mutations would be very useful [7].

For each of the eight BC women carrying a deleterious or likely deleterious ATM mutation, only one relative presented a haematological malignancy. In six cases, this relative was a first degree relative and in two cases a second degree relative (Fig. 3). The disease was leukaemia in seven cases and Kaposi sarcoma occurring at age 55 in the remaining case. Three acute lymphoid leukaemia cases occurred during childhood at the ages of 3,8 , and 10 years; one leukaemia case occurred at 44 years and the three other cases were late-onset leukaemia, occurring after the age of 80. No blood samples which would have been required for ATM mutation co-segregation study from both cases with haematological malignancies and with breast cancer were obtained, most of the cases being deceased or lost of follow-up.

The estimated frequency of A-T heterozygotes in our series is $6.56 \%$ (95\% CI: 2.16-10.95), a significantly higher figure than that observed in the general population which is estimated to be between 0.3 and $0.6 \%$ [12, 14]. Although a trend towards an increased frequency of ATM carriers was observed in our series, it was not different from that observed in a population of familial BC women not selected for haematological malignancy in relatives, as the frequency of $A T M$ carriers was $2.70 \%$, a value situated in the confidence interval 2.16-10.95 estimated in our study [14]. It is noteworthy that, although the RR of haematological malignancies in ATM heterozygote carriers may be highSIR 37 in Olsen's study-[11], the absolute risk remains low, as the incidence of haematological malignancies is low in the general population. Thus the availability of familial aggregations of both breast cancer and haematological malignancies is low, limiting the power of such study. Finally, although the expected final classification of some UVs in the deleterious mutation group and that of some rare polymorphic allele will increase this frequency, a larger set of patients with a control group of BC women with no family history of haematological malignancy needs to be studied to determine whether the presence of relatives with leukaemia and/or lymphoma in $\mathrm{BC}$ families is a predictive factor for ATM mutation.

Acknowledgments We would like to thank the patients for their participation in this study. We thank Patricia Legoix-Né for her help in sequencing analyses, Catherine Dubois d'Enghien for her help in the selection of A-T DNA controls, and Nadine Andrieu for her critical reading of the manuscript. This work received financial support from ANR (Agence Nationale pour la Recherche), RNTS program.

\section{References}

1. Collaborative group on hormonal factors in breast cancer (2001) Familial breast cancer: collaborative reanalysis of individual data from 52 epidemiological studies including 58, 209 women with breast cancer and 101, 986 women without the disease. Lancet 358(9291):1389-1399. doi:10.1016/S0140-6736(01)06524-2

2. Easton DF (1999) How many more breast cancer predisposition genes are there? Breast Cancer Res 1(1):14-17. doi:10.1186/bcr6

3. Shiloh Y (2003) ATM and related protein kinases: safeguarding genome integrity. Nat Rev Cancer 3(3):155-168. doi:10.1038/ nrc1011

4. Lavin MF (2008) Ataxia-telangiectasia: from a rare disorder to a paradigm for cell signalling and cancer. Nat Rev Mol Cell Biol 9(10):759-769. doi:10.1038/nrm2514

5. Chun HH, Gatti RA (2004) Ataxia-telangiectasia, an evolving phenotype. DNA Repair (Amst) 3(8-9):1187-1196. doi:10.1016/ j.dnarep.2004.04.010

6. Concannon P, Gatti RA (1997) Diversity of ATM gene mutations detected in patients with ataxia-telangiectasia. Hum Mutat 10(2):100-107. doi:10.1002/(SICI)1098-1004(1997)10:2<100:: AID-HUMU2 $>3.0 . \mathrm{CO} ; 2-\mathrm{O}$

7. Taylor AM, Byrd PJ (2005) Molecular pathology of ataxia telangiectasia. J Clin Pathol 58(10):1009-1015. doi:10.1136/jcp. 2005.026062

8. Swift M, Morrell D, Massey RB, Chase CL (1991) Incidence of cancer in 161 families affected by ataxia-telangiectasia. N Engl J Med 325(26): 1831-1836

9. Easton DF (1994) Cancer risks in A-T heterozygotes. Int J Radiat Biol 66(Suppl 6):S177-S182. doi:10.1080/09553009414552011

10. Janin N, Andrieu N, Ossian K, Lauge A, Croquette MF, Griscelli C, Debre M, Bressac-de-Paillerets B, Aurias A, Stoppa-Lyonnet D (1999) Breast cancer risk in ataxia telangiectasia (AT) heterozygotes: haplotype study in French AT families. Br J Cancer 80(7):1042-1045. doi:10.1038/sj.bjc.6690460

11. Olsen JH, Hahnemann JM, Borresen-Dale AL, Brondum-Nielsen K, Hammarstrom L, Kleinerman R, Kaariainen H, Lonnqvist T, 
Sankila R, Seersholm N, Tretli S, Yuen J, Boice JD, Tucker M (2001) Cancer in patients with ataxia-telangiectasia and in their relatives in the nordic countries. J Natl Cancer Inst 93(2):121127. doi:10.1093/jnci/93.2.121

12. Thompson D, Duedal S, Kirner J, McGuffog L, Last J, Reiman A, Byrd P, Taylor M, Easton DF (2005) Cancer risks and mortality in heterozygous ATM mutation carriers. J Natl Cancer Inst 97(11):813-822

13. Ahmed M, Rahman N (2006) ATM and breast cancer susceptibility. Oncogene 25(43):5906-5911. doi:10.1038/sj.onc.1209873

14. Renwick A, Thompson D, Seal S, Kelly P, Chagtai T, Ahmed M, North B, Jayatilake H, Barfoot R, Spanova K, McGuffog L, Evans DG, Eccles D, Easton DF, Stratton MR, Rahman N (2006) ATM mutations that cause ataxia-telangiectasia are breast cancer susceptibility alleles. Nat Genet 38(8):873-875. doi:10.1038/ ng 1837

15. Taylor AM, Metcalfe JA, Thick J, Mak YF (1996) Leukemia and lymphoma in ataxia telangiectasia. Blood 87(2):423-438

16. Vorechovsky I, Luo L, Dyer MJ, Catovsky D, Amlot PL, Yaxley JC, Foroni L, Hammarstrom L, Webster AD, Yuille MA (1997) Clustering of missense mutations in the ataxia-telangiectasia gene in a sporadic T-cell leukaemia. Nat Genet 17(1):96-99. doi: 10.1038/ng0997-96

17. Stilgenbauer S, Schaffner C, Litterst A, Liebisch P, Gilad S, BarShira A, James MR, Lichter P, Dohner H (1997) Biallelic mutations in the ATM gene in T-prolymphocytic leukemia. Nat Med 3(10):1155-1159. doi:10.1038/nm1097-1155

18. Stoppa-Lyonnet D, Soulier J, Lauge A, Dastot H, Garand R, Sigaux F, Stern MH (1998) Inactivation of the ATM gene in T-cell prolymphocytic leukemias. Blood 91(10):3920-3926

19. Stankovic T, Weber P, Stewart G, Bedenham T, Murray J, Byrd PJ, Moss PA, Taylor AM (1999) Inactivation of ataxia telangiectasia mutated gene in B-cell chronic lymphocytic leukaemia. Lancet 353(9146):26-29. doi:10.1016/S0140-6736(98)10117-4

20. Bullrich F, Rasio D, Kitada S, Starostik P, Kipps T, Keating M, Albitar M, Reed JC, Croce CM (1999) ATM mutations in B-cell chronic lymphocytic leukemia. Cancer Res 59(1):24-27

21. Camacho E, Hernandez L, Hernandez S, Tort F, Bellosillo B, Bea S, Bosch F, Montserrat E, Cardesa A, Fernandez PL, Campo E (2002) ATM gene inactivation in mantle cell lymphoma mainly occurs by truncating mutations and missense mutations involving the phosphatidylinositol-3 kinase domain and is associated with increasing numbers of chromosomal imbalances. Blood 99(1):238-244. doi:10.1182/blood.V99.1.238

22. Gumy-Pause F, Wacker P, Maillet P, Betts DR, Sappino AP (2006) ATM alterations in childhood non-Hodgkin lymphoma. Cancer Genet Cytogenet 166(2):101-111. doi:10.1016/j.cancergencyto. 2005.09.005

23. Liberzon E, Avigad S, Stark B, Zilberstein J, Freedman L, Gorfine M, Gavriel H, Cohen IJ, Goshen Y, Yaniv I, Zaizov R (2004) Germ-line ATM gene alterations are associated with susceptibility to sporadic T-cell acute lymphoblastic leukemia in children. Genes Chromosomes Cancer 39(2):161-166. doi: $10.1002 / \mathrm{gcc} .10306$

24. Geoffroy-Perez B, Janin N, Ossian K, Lauge A, Croquette MF, Griscelli C, Debre M, Bressac-de-Paillerets B, Aurias A, StoppaLyonnet D, Andrieu N (2001) Cancer risk in heterozygotes for ataxia-telangiectasia. Int J Cancer 93(2):288-293. doi:10.1002/ ijc. 1329

25. Johns MB Jr, Paulus-Thomas JE (1989) Purification of human genomic DNA from whole blood using sodium perchlorate in place of phenol. Anal Biochem 180(2):276-278. doi:10.1016/00032697(89)90430-2

26. Weber J, Barbier V, Pages-Berhouet S, Caux-Moncoutier V, Stoppa-Lyonnet D, Viovy JL (2004) A high-throughput mutation detection method based on heteroduplex analysis using graft copolymer matrixes: application to Brca1 and Brca2 analysis. Anal Chem 76(16):4839-4848. doi:10.1021/ac049878p

27. Weber J, Looten R, Houdayer C, Stoppa-Lyonnet D, Viovy JL (2006) Improving sensitivity of electrophoretic heteroduplex analysis using nucleosides as additives: application to the breast cancer predisposition gene BRCA2. Electrophoresis 27(8):14441452. doi:10.1002/elps.200500797

28. Weber J, Miserere S, Champ J, Looten R, Stoppa-Lyonnet D, Viovy JL, Houdayer C (2007) High-throughput simultaneous detection of point mutations and large-scale rearrangements by CE. Electrophoresis 28(23):4282-4288. doi:10.1002/elps.2007 00010

29. Houdayer C, Gauthier-Villars M, Lauge A, Pages-Berhouet S, Dehainault C, Caux-Moncoutier V, Karczynski P, Tosi M, Doz F, Desjardins L, Couturier J, Stoppa-Lyonnet D (2004) Comprehensive screening for constitutional RB1 mutations by DHPLC and QMPSF. Hum Mutat 23(2):193-202. doi:10.1002/humu. 10303

30. Houdayer C, Dehainault C, Mattler C, Michaux D, Caux-Moncoutier V, Pages-Berhouet S, d'Enghien CD, Lauge A, Castera L, Gauthier-Villars M, Stoppa-Lyonnet D (2008) Evaluation of in silico splice tools for decision-making in molecular diagnosis. Hum Mutat 29(7):975-982. doi:10.1002/humu.20765

31. Tavtigian SV, Samollow PB, de Silva D, Thomas A (2006) An analysis of unclassified missense substitutions in human BRCA1. Fam Cancer 5(1):77-88. doi:10.1007/s10689-005-2578-0

32. Tavtigian SV, Greenblatt MS, Lesueur F, Byrnes GB (2008) In silico analysis of missense substitutions using sequence-alignment based methods. Hum Mutat 29(11):1327-1336. doi:10.1002/ humu.20892

33. Austen B, Skowronska A, Baker C, Powell JE, Gardiner A, Oscier D, Majid A, Dyer M, Siebert R, Taylor AM, Moss PA, Stankovic T (2007) Mutation status of the residual ATM allele is an important determinant of the cellular response to chemotherapy and survival in patients with chronic lymphocytic leukemia containing an 11q deletion. J Clin Oncol 25(34):5448-5457. doi: 10.1200/JCO.2007.11.2649 